University of Massachusetts Amherst ScholarWorks@UMass Amherst

History Department Faculty Publication Series

History

2019

\title{
Football Outside the Schools in the United States before Codification
}

Brian D. Bunk

University of Massachusetts - Amherst, bunk@history.umass.edu

Follow this and additional works at: https://scholarworks.umass.edu/history_faculty_pubs

\section{Recommended Citation}

Bunk, Brian D., "Football Outside the Schools in the United States before Codification" (2019). The Early Development of Football: Contemporary Debates. 217.

https://doi.org/10.4324/9780429292224

This Article is brought to you for free and open access by the History at ScholarWorks@UMass Amherst. It has been accepted for inclusion in History Department Faculty Publication Series by an authorized administrator of ScholarWorks@UMass Amherst. For more information, please contact scholarworks@library.umass.edu. 


\section{Football Outside the Schools in the United States before Codification}

Published as: Brian D. Bunk, "Football in the United States before Codification and what it can tell us about the "Origins Debate"" in The Early Development of Football: Contemporary Debates Graham Curry, ed. (London: Routledge, 2019).

Throughout the first half of the nineteenth century, football in the United States was an established pastime for children and had also been popular at schools and colleges. In certain circumstances adult men outside of the schools played the sport, using football as means of confirming social bonds centered on educational experience, occupation, ethnic identity or military service. Generally, these types of matches fall into four categories although there was often considerable overlap between them: First, nostalgia football played as a way of recalling schooldays or childhoods. Second, holiday football, a popular version of mob football generally played on special occasions or as part of ethnic festivals. Third, military football played by soldiers during the United States Civil War (1861-1865). Fourth, club football organized by teams outside the schools. Although games from the first three categories were not uncommon, matches between formal established clubs were rare.' Despite some newspaper articles containing the names of football clubs there are no documented match reports describing club football games until after the Civil War. ${ }^{2}$ In fact, formal organized clubs detached from educational institutions really do not begin to form until the 1870 s.

Despite the paucity of match reports, sources suggest that games of all types increased or at the very least received more attention from newspapers during the $1850 \mathrm{~s}$ and 1860s. Therefore, at the same time that some colleges began efforts to end mob-style football traditions on campus it appears that the game had slowly begun to grow outside 
of the educational institutions. When rules for such matches are known however they generally resembled the loosely organized contests common in educational settings or they came from England and were especially influenced by the sport as practiced at Rugby school. At a time when baseball was being actively promoted as an authentically American sport, formal football's clear dependence on imported models may have limited its attractiveness. On a structural level baseball had begun to establish itself before the Civil War and so gained in popularity both during the conflict and after hostilities ended. Research by baseball historian John Thorn has shown that at least five clubs had organized before 1845 and by 1856 the number had grown to twelve.

Discussions about the formation of a standard set of rules soon began and the first national convention took place in $1857 .{ }^{3}$ In the antebellum period football did not develop in the same way as there was virtually no tradition of adult clubs outside the schools and the process of forming a national organization only really began in the 1880 s. Football continued to be played once the Civil War began in 1861 but the chaotic and sometimes violent game played in army camps did not make the transition to life after the war. Nevertheless, football returned to the schools in the late 1860 s and 1870 s where it eventually evolved to become the dominant form of the sport in the US. ${ }^{4}$

\section{Nostalgia Football}

One of the longest running annual football games played by adults illustrates the ways that many alumni saw the activity as a way of reconnecting with old friends (and sometimes old rivals) while fondly recalling their school days. Woodward College was an educational institution founded in Cincinnati by William Woodward in 1831.5 Originally from Connecticut, Woodward relocated to the Midwest in 1791 and made his 
fortune in real estate and by marrying his former ward who had inherited money. The institution began as a High School in 1831 and the trustees obtained a college charter five years later. Between 1836 and 1851 when it shut down the college enrolled 1,377 pupils although most did not complete a formal course of study. ${ }^{6}$ A few years after its closure Woodward alumni organized a reunion and formed an association open to any student who had attended either the high school or the college. The first meeting of the group took place on September 27, 1855 and they played a football game as part of the events. The contest took place on an unused Potters field near the Orphan Asylum and over one hundred men of all ages participated in the match. As with most versions of youth football the rules of the game were unclear but it seemed to allow for both kicking and carrying the ball. The description of that first match recounts how a clergyman caught the ball before kicking it away and that the first of twenty games ended when the "the ball at last [was] carried home."' Despite the fact that the men were adults and had established positions in society and business the game nevertheless resulted in ripped clothes, a nose bleed and plenty of players falling to the ground.

The first meeting of the Woodward association sparked a long running tradition that brought former students back to Cincinnati annually for at least the next several decades. Each year's activities included speeches and a banquet but the first day always began with a football game except on a few occasions when war or inclement weather forced its cancellation. In this case the adult men played football games as a form of nostalgia for their school days. Often the speeches and other activities included fond reminiscences of former teachers, classmates and even other pastimes including mumblety-peg and shinny. ${ }^{8}$ Despite its regularity the annual game remained an informal 
type of contest, played by adults as a way of recalling and recreating their childhood experiences. At no point did they make any attempts to formalize the rules or to organize into anything but rough sides. It was in some sense an extension of youth football played into adulthood and did not indicate any sort of increased level of organization.

\section{Holiday Football}

Perhaps because holidays often meant a respite from work they were also a time when men gathered to play football. Often such activities were very public and involved large numbers of players. On Thanksgiving Day 1853, for example, "hundreds" of men and boys engaged in football play on Boston Common..$^{\text {At }}$ other times the holiday game was played on a much smaller and more intimate level. Such matches are generally only known to us when mention of them emerges as part of a larger story unrelated to sports. As a result, it is impossible to known how often such games were played or what rules they followed. One example from 1855 only surfaced because of newspaper stories reporting on the murder of William Sumner in Boston. The victim met two "candy-Shop Coquets" at a tea house and was convinced to follow them home. Once there two men accused him of improper advances towards the women and savagely beat him. Eventually Summer died as a result of his wounds. Testimony from family members during an inquest into the crime revealed that despite his injuries he had played football on Thanksgiving with family members..$^{10}$

A detailed examination of a match played in Chelsea Massachusetts in 1848 shows that in addition to its connections with holiday festivities football also played a role in the masculine culture of the time. Fire company four based in Chelsea and 
nicknamed the Hamiltons played a Thanksgiving Day football game in Winnisimmet square. The original newspaper report on the match shows that it was a one-off contest played on a particular occasion and that there is no indication of how many players took part or what type of rules may have been involved." Like firemen in other large cities during this period, the men of company four socialized together and had a sometimes contentious rivalry with other local fire companies. ${ }^{12}$ These companies became bastions of a certain type of brash masculinity and "formality and restraint, which grew increasingly important as markers of status among urban Americans of the emerging middle class, were anathema to firemen." Physicality, rowdiness and a resistance to evangelical Christian norms also emerged as important part of firehouse culture. ${ }^{13}$

Understanding the broader context of 1848 football game allows us to better gauge its significance. Likely what happened on Thanksgiving is that members of the fire company had a holiday feast that may have included heavy drinking. In keeping with the established tradition of having a football match the men decided to play in the town square. Given the nature of fire culture the play may have been especially boisterous and/or physical and the newspaper report described it as "fast and furious." Eventually the constable arrived, ordered them to stop and attempted to grab a young boy holding the football. Although technically not part of the company it was common for boys to socialize at the firehouse and tag along with the men. ${ }^{14}$ At that point a member of the Hamiltons seized the ball and "gave it a mooner" while exclaiming "Alone, and on my own responsibility, I set this ball in motion." As the action continued unabated the constable left the scene to report the men to the city selectmen for prosecution. While the game was being played other people including deacons from neighboring churches as 
well as other pious citizens, referred to as "saints" in the original article, walked through the square. Given the belligerent masculine culture and anti-Christian sentiment associated with firemen it seems they began to throw the ball at the interlopers' feet and shout derisively that they would be fined by the constable for kicking the ball away.

Other informal games took place on special occasions such as outings sponsored by ethnic associations. In these cases, football was a part of the celebratory experience, a respite or break from everyday life and did not represent any sort of formal sporting organization. The list of activities scheduled for a German Volksfest held in New Orleans in May 1858 included "foot balls" among the recreations. An advertisement for the festivities offered prizes for some of the sporting events and invited everyone to participate..$^{15}$ Another newspaper described the scene that took place on May 16 including a parade featuring authentic German costumes as well as "a portly Saxon, astride a beer barrel, representing, as best he could, the god of the beer drinkers." Although primarily a German cultural festival the event seemed to have attracted a large crowd and "the grounds swarmed with jovial life, and the flying horses, the dance, gymnastic exercise and sports of almost all descriptions became separate centres of attractions." ${ }_{16}$ Since no description of the match play has survived it is impossible to make any claims about the nature of the contest let alone its rules. ${ }^{17}$

In addition to matches played as part of holiday excursions, football could also be included as part of a series of athletic events designed to make money. Profit driven matches in the United States were more closely related to the types of games put on by ethnic associations than they were to more organized developments in England that may have showed early indications of commercialization..$^{18}$ Instead of being celebrations of 
community and heritage however the games promoted by entrepreneurs were designed as profit making entertainments where city dwellers could attend as spectators or compete to win prizes.

An early example is the opening of the Cricket and Archery Grounds in East Boston in 1843. Beginning in September of that year George H. Andrews and John Sheridan began advertising that they had recently leased the grounds and would be holding a three-day athletic festival to celebrate the facility's inauguration. According to the Boston Evening Transcript the location had previously been a racecourse and was centrally located near a tavern called the Maverick House. Despite being situated near a drinking establishment there is no indication that the owners of the pub had anything to do with organizing or sponsoring the football game or other activities, something that occurred with small scale games in England. ${ }^{19}$ Instead the driving force may have been Sheridan who was an athletics instructor, proprietor of the Boston Gymnasium and later operated a "pistol gallery." ${ }^{20}$ The scheduled events included a wide variety of games and recreations such as cricket, archery, running, wrestling and football. Admission to the athletic festival was 25 cents for adults (12 1/2 cents for youths) and prizes were awarded to the victors. The final event listed on each day's schedule was a football match between teams of twelve men each. ${ }^{21}$ While football appeared on the list it was not the main focus of the event but rather part of a diverse program featuring a range of different competitions.

Only one account describes results and it only covered the first of the three days of competition. Published in the Boston Evening Transcript on October 20 it noted that a large crowd attended the previous day's events and that Mr. Dearing's party won the 
football match. Because the article contains no other information it's impossible to know more about the match or the sides involved.2. Since anyone could apply to compete in the event and because the report called the winning squad a "party" implies that this was a temporary association, perhaps a group of friends or maybe even random players led or organized by Dearing.

What is clear is that a subsequent advertisement for the second day of the threeday festival in 1843 contained an important change in the description of the football match. Instead of a contest between two teams of twelve men the game was now listed as "A general Football Match in which all persons can join; two Footballs on the ground." ${ }^{23}$ It is unkown why the change was made but it could indicate that there was simply not enough interest in having a small-sided game and instead people preferred to participate in what may have been more like a traditional mob-type contest. Such an interpretation is supported by the fact that the author of the lone match report of the contest from October 20 wrote that while the festival was an enjoyable overall experience the proprietors needed to do a better job of managing the crowd to allow for better viewing of the various competitions..$^{24}$ Although the original advertisements called for three small-sided football games to be played there is evidence that only one actually took place and there is no information about the rules or scoring. The sources also indicated that the promoters eventually scrapped the idea of such contests in favor of a less structured activity that likely resembled mob-type games. Indeed, an advertisement for another set of activities planned for November 2, 1843 included notice that "A general Football Match" would be played making no mention of the number of players or offering any prize..$^{25}$ 
The following year the promoters once again placed advertisements in the newspaper for athletic competitions in East Boston but only once did they mention football. The program was for a July Fourth celebration and listed a variety of entertainments including a foxhunt, greased pole climb, pigeon shooting and football. The paper offered no other information and no description of the event as it took place exists. The ad only indicates that some type of football was scheduled to be played and that its status as a pastime was on a par with activities such as catching the pig. Instead of football the marquee event of the day was a foot race for a prize totaling $\$ 500$. None of the other events held at the Cricket and Archery Ground in 1844 or 1845 included any further mentions of football and instead the sponsors seem to have shifted to organizing less participatory events. ${ }^{26}$

\section{Military Football}

Accounts from the Civil War provide some of the earliest and most plentiful depictions of football outside of the schools. These contests had features that resembled the mob-style games played in the schools and often took place on holidays. The federal government felt the sport was beneficial for both the men's bodies and their minds. In outlining the best ways to protect the health and morale of its soldiers, the United States Sanitary Commission wrote that "when practical, amusements, sports, and gymnastic exercise should be favored amongst the men" and named football as one possible recreation. ${ }^{27}$ Near the end of the first year of war a survey of army units reported that 42 regiments practiced "systematic athletic recreations" including football while 156 did not. ${ }^{28}$ During the preparations for operations the military at times made special efforts to provide soldiers with the opportunity to play football. When Union forces set out to 
capture Port Royal Sound, South Carolina, one of the conflict's first large scale assaults, newspaper reports stated that "several hundred footballs for the amusement of the troops" were among the supplies..$^{29}$ Reports from other units throughout the war years confirm that troops originating in different parts of the country including the Southern states played football. ${ }^{30}$ Given the informal nature of the games, it seems likely that these contests had few if any specific rules and those that did exist such as the size of the playing field or even goals could have been dictated by local circumstance. Military football, as with other events such as the games held in East Boston in 1843 was often part of a general program of activities that could be played by large numbers of people, especially during holiday celebrations. In his history of the Vermont Tenth Regiment for example, E. M. Haynes describes a scene from the unit's Thanksgiving Day activities. The day began with "a grand game of foot-ball" followed by running races, pistol shooting contests and the release of a greased pig..$^{31}$

Evidence shows that like many mob-style versions of the sport, military football could and did devolve into actual violence. Early in the war, several newspapers reported an incident that took place between men from Rhode Island. While training at Camp Stevens in Massachusetts a group of soldiers "were kicking football with some citizens, [when] an altercation commenced between them." After Lieutenant George H. Tabor and the post commander rushed to stop the melee, one of the soldiers knocked Tabor down and stomped on his head breaking his cheek bone. Soon other members of the unit rushed to grab the offender and his friends. After he came to the officer's aid nineteen-year old drummer James Simmons was stabbed in the abdomen and died of his wounds a few days later ${ }^{32}$ From the newspaper reports it seems that the most seriously wounded men, Tabor 
and Simmons were not originally part of the group involved in kicking the football. As a result, the murder of Simmons only indirectly resulted from the football match but the incident still shows that such games could become quite heated, sometimes turning into out and out brawls.

\section{Club Football}

While informal or ad hoc matches occurred with some frequency, formal organized football games played between clubs were rare. As the sporting press grew during the 1850s coverage of football expanded although it received considerably less attention than other pastimes. Efforts by the New York Clipper, one of the country's leading sporting publications, to encourage the growth of the sport reveal the limited spread of football outside youth games, those played in the schools and the informal matches described above. English publications such as Bell's Life in London had long been popular in the United States and soon native sporting periodicals began to appear including the Spirit of the Times founded in New York City by William Trotter Porter in 1831. Initially the press covered pastimes included horse racing and cricket but stories on baseball and prizefighting became increasingly common over time. George Wilkes began publishing the Police Gazette in 1845 and eventually purchased the Spirit of the Times in 1856. ${ }^{33}$ Despite a growing interest in a wide variety of sports Wilkes' publications made virtually no mention of football until after the Civil War.

Harrison Trent Fulton published the first edition of the New York Clipper in 1853 and the editor was Philadelphia born Francis "Frank" Queen. Although he had little formal education Queen had worked in the newspaper business before becoming editor of 
the Clipper and eventually purchased ownership of the paper in $1855 .^{34}$ Like his competitors, Queen's paper wrote about sports such as pedestrianism, cricket and prizefighting but soon the focus was on baseball. The first mention of the sport in the pages of the Clipper came in 1853 but rose dramatically after Henry Chadwick became the paper's field sports editor in $1858 .^{35}$ The Clipper distinguished itself from its rivals however by encouraging the playing of football and reporting, although in a limited and piecemeal way, on the results.

On December 13, 1856 the paper attempted to launch the formation of formal football organizations by asking "Who is up for a "Foot Ball Club?" ${ }_{36}$ According to a follow-up story a week later some young men in Philadelphia had developed an interest in the sport but "never having seen any instructions concerning the correct mode of playing" requested more information. ${ }^{37}$ In response, on December 20, 1856 the Clipper published the first printed football rules aimed at adults in the US. The code was copied directly from the 1856 Manual of British Rural Sports with only the mention of Rugby school excised from the original text. ${ }^{38}$ The rules were simple with only two numbered laws. The first declared "The ball itself is the only thing required by this game, except a large field to play in.” The ball was constructed using an inflated bladder eight or nine inches in diameter covered with calf leather. The second rule explained how to mark off the playing field and the general style of play. The boundaries of the pitch were to be set at fifty to sixty yards apart extending up to one hundred if there was enough room. The result was a square rather than a rectangular playing area. The rules did not call for any sort of goal markers instead a team scored by propelling the ball across the opponent's end line. 
The assembled players selected two captains and a coin toss determined who would be the first to select someone for his side. The rules did not stipulate a certain number of players for each side declaring only that the leaders took turns selecting participants until all had been chosen for a squad. Afterwards the two teams faced off in the middle of the pitch before one captain began the game by kicking the ball toward his opponents' side of the pitch. The receiving team was then allowed to return the ball "either by a kick, or carrying it, if preferred." This was a key feature of the rules as it clearly indicated that the earliest published football code in the US allowed for both kicking and carrying the ball. The game continued and the team not in possession could "throw down the ball-carrier or kicker by any means in their power." This is another important feature because it seemed to allow for virtually any type of physical contact including tripping and tackling. In fact, the code stated that tripping from behind was the most commonly employed way to bring down a rival player. Although it is not spelled out in the rules it would follow that once brought down the player would likely have to give up possession of the ball. Nothing in the regulations indicated if the ball carrier was required to kick it away to his opponents as at the start of the match or had to relinquish the ball in some other way. Likewise, the code was silent about the ways that teammates could pass the ball or if there was anything like an offside rule. The object of the game was to propel the ball over the other team's end line resulting in the end of the match. The article clearly stated that the ball had to be kicked over the goal line thus implying that carrying it across was not legal..$^{39}$

The efforts of the Clipper to promote the growth of the sport during this period largely proved ineffective. A year after publishing the first set of rules the paper 
concluded that football "does not meet with much favor in this vicinity" presumably meaning New York City where the periodical was based. The paper did claim however that the sport was popular in Massachusetts with "clubs forming in great numbers." ${ }^{40}$ The story may have been referencing school teams since football at Harvard had already attracted some attention from the press and the only Massachusetts clubs mentioned by name in the Clipper were the equivalent of high school sides. ${ }^{41}$ In addition contemporary newspapers in Massachusetts made no mention of the supposed large number of football clubs that had been or were in the process of forming. Taken together football's yearly mentions in the Clipper show that while the game remained popular among schoolboys and college students it made little headway outside of educational institutions. In 1858, as if to emphasize that the game was largely one for young people and students, the Clipper published a long poem purporting to describe a football game at Spring Hill College in Alabama and reserved an entire page for an excerpt and illustration of a match from the book Tom Brown's School Days. ${ }^{42}$ By December 1859, almost three years to the day after first advancing the idea of formal football clubs, the newspaper continued to promote the game as an ideal winter sport. As if to demonstrate the lack of existing teams the Clipper once again asked readers "Who is to have the honor of organizing the first foot ball club?" In order to facilitate the growth of such groups the newspaper published two English public school codes - Rugby and Eton. ${ }^{43}$

Four years later the Clipper took notice of the early meetings of the Football Association in England declaring "We anticipate the code, as digested, in a couple of weeks." ${ }_{44}$ When the newspaper finally printed a set of football rules on December 3, 1864 they did not credit them to the English FA but instead simply presented them as the 
"revised Rules for Football." ${ }^{45}$ Curiously the code that appeared in the Clipper was not the final Association rules but instead was the original code as determined by the meetings in late November 1863 and subsequently published in British periodicals including Bell's Life in London and the Sporting Gazette. ${ }^{46}$ That is to say the association code as first published in the United States included both the carrying and hacking provisions that were later expunged from the final FA version. The reasons for publishing the original rules are unknown but could indicate that the editors favored a Rugby-style code over the alternatives.

The majority of published accounts of football games in periodicals such as The Clipper turn out to be informal contests and virtually no press reports of formal matches have surfaced. In addition, the country's top sporting newspaper exhibited little knowledge of such games and the earliest published rules allowed for both kicking and carrying the ball. A few tantalizing mentions indicate that a handful of football clubs had been formed but they are often named in only one report and there are no stories describing the rules or results of any matches. Some of the teams emerged out of existing ethnic or other sporting associations while others may have been purposely formed to play football but there are no indications that they ever played games against other clubs.

Several notices from New York City show that an established cricket club also played football. First organized in 1838, the St. George's cricket club was closely connected to the social association of the same name ${ }^{47}$ Newspaper accounts from the 1840s show how the club competed against cricket teams from Philadelphia and Toronto and these contests often involved quite large stakes. At one game versus Toronto in 1844 for example the clubs reportedly played for between $\$ 500$ and $\$ 2,000$ with another 
$\$ 50,000$ wagered on the outcome. ${ }^{48}$ Although the cricket club had been organized in 1838 , it wasn't until 1854 that a communique, likely composed by a member of the organization and published in slightly different forms by The Spirit of the Times and The Clipper, stated that the organization had also been playing football. The brief notice asserted that the St. George's Foot Ball Club had been in existence in New York since 1842 and although it had previously met only once per year the club was now preparing to play more regularly. ${ }^{49}$ Historian David Kilpatrick concludes that such information may have been given with the goal of "showing itself" and presumably attracting more members and/or spectators to the club. Nevertheless, the only further mention of the football club so far discovered appeared in the New York Herald in November 1854 alerting "members and friends" that the annual Thanksgiving match would kick off at ten o'clock..$^{\text {so }}$ The St. George's cricket club had an established history of playing against other teams, including contests featuring high stakes wagers. Yet, the football club either chose not to compete against outsiders or was unable to find opponents. Instead the football match occurred annually as part of holiday celebrations at Thanksgiving and appeared to involve only members of the club and their friends.

The most intriguing case involving non-schoolboy football teams might be the city of Baltimore where the press printed meeting notices for five clubs between 1859-60: Cottage, Mount Vernon, Waverly, Olympics and the East Baltimore Hurling and Football Club. Three of the four (Mount Vernon, Waverly and East Baltimore) were likely organized within specific neighborhoods of the city. Most of the announcements listed club officers and directed members to convene at an established place of exercise on a particular day or days..$^{51}$ Such detail implies a continuous existence along with a level of 
organization. Nevertheless, there is no evidence about what rules may have governed club activities, whether or not the clubs had any connection to one another or that they ever played games against other clubs. Indeed, most of the notices describe the activity as "exercise" rather than an organized match and may indicate that only members of the club participated. When the city's earliest baseball teams formed around this same time they only played games amongst club members for the first year or so..$^{52}$

It has proven difficult to identify any of the football club members with any certainty except John Southgate Lemmon, president of the Mount Vernon Foot Ball Club. In the 1860 US Census Lemmon was 19-year-old clerk who lived at home with his family ${ }^{53}$ Lemmon and the club's secretary Joseph L. Toy both attended the University of Maryland and the men may have still been students when the football club formed..$^{54}$ If that was the case it would be similar to the Oneida Football Club organized by schoolboys in Boston in 1862 and often called the country's first football club.s5 The Oneida's only known matches were against other schoolboy teams. Although Lemmon was reported to be the president of the Mount Vernon Foot Ball Club he may also have turned out for the Waverly Base Ball Club. A "Mr. Lemmon" was singled out for his fine play at shortstop in a game between the Waverly and Excelsior clubs on September 10, 1860 and the box score of the rematch on October 17 included the surname Lemmon..$^{56}$

\section{Conclusion}

The available evidence suggests that small-sided mainly kicking games between formal football clubs were not widely played in the US before 1863 . Most of the match reports describe informal contests between loosely organized squads that were often 
played on special occasions and holidays. Although some clubs have been named there are as of yet no surviving descriptions of games and there is no way of knowing if these groups competed with other sides or simply played football among club members. The codes published in periodicals like the Clipper generally allowed players to carry the ball and to commit a great deal of physical contact - elements that would later be incorporated into what eventually became American or gridiron football. As such the evolution of football outside the schools in the United States seemed to foreshadow the direction the sport would later take. However, because we have scant evidence that organized football was widely played it is difficult to determine if and in what ways it influenced later developments.

' Of these categories only the last one, club football corresponds with Adrian Harvey's formal non-public school teams. Unlike his claims about England, such clubs were exceedingly rare in the United States before the 1870s. Adrian Harvey, "The Public Schools and Organized Football in Britain: Fresh Perspectives on Old Paradigms" International Journal for the History of Sport vol. 33, 3 (2016): 273, 274. In contrast to Harvey, Tony Collins concludes that even in England "Organised football matches were few and far between during the first half of the nineteenth century." Tony Collins, How Football Began. A Global History of How the World's Football Codes were Born (New York: Routledge, 2018), 14.

${ }^{2}$ Although sometimes called the first formal football club in the United States the Oneida Football Club was organized by students and so would fall under the category of schools football. See Steven Apostolov, "Native Americans, Puritans and 'Brahmins': Genesis, Practice and Evolution of Archaic and Pre-Modern Football in Massachusetts" Sport in Society Vol. 20, 9 (2017), 1262-1266 and Kevin Tallec Marston and Mike Cronin "The Origins of Foot-ball in America: Foundation Myths, Memorialization and Rethinking the Oneida Football (soccer) Club" in Mapping U.S. Soccerscapes, 1863-1913: Immigrants, Industries, and Individuals Chris Bolsmann and George N. Kioussis, eds. (Knoxville: University of Tennessee Press, forthcoming).

${ }^{3}$ John Thorn, Baseball in the Garden of Eden (New York: Simon \& Schuster, 2011), 31, 35 . 
${ }^{4}$ Intercollegiate or American football was heavily influenced by British models. Collins, How Football Began, chap. 15.

${ }^{5}$ Much of the data on early football in the US comes from newspaper reports that were first reported by Mel Smith. He published his findings as Evolvements of Early American Foot Ball (AuthorHouse, 2008), Roy Hay, Adrian Harvey, and Mel Smith. "Football Before Codification: the Problems of Myopia." Soccer and Society 16, no. 2 (2014) and produced updated lists for the American Soccer History Archives http://homepages.sover.net/ spectrum/. Scholars of early football in the United States owe Smith a debt for all of the work he has done to record and preserve the game's history. Nevertheless, his focus has mainly been on compiling mentions of football and he has not generally sought to analyze and contextualize his findings.

${ }^{6}$ Old Woodward. A Memorial relating to Woodward High School, 1831-1836 and Woodward College, 1836-1851 in the City of Cincinnati (Cincinnati: Old Woodward Club, 1884), 11, 13, 31, 40, 54.

Old Woodward, 71, 75, quote on 74

${ }^{8}$ Old Woodward, 82ff, 88.

9 "Foot Ball on the Common" Boston Herald November 25, 1853.

${ }^{10}$ Two men were ultimately convicted of assaulting William Sumner. "City Intelligence" Boston Courier November 26, 1855; "City Intelligence” Boston Courier December 20, 1855 "Refusal to Pardon Coburn and Dalton” Boston Evening Transcript July 8, 1856.

${ }^{11}$ Hay, Harvey and Smith cite this as an example of a small sided game played in the US. Hay, Roy, Adrian Harvey, and Mel Smith. "Football Before Codification: the Problems of Myopia." Soccer and Society 16, no. 2 (2014), 161.

${ }^{2}$ Amy S. Greenberg, Cause for Alarm. The Volunteer Fire Department in the NineteenthCentury City (Princeton University Press, 1998), 53. For examples involving the Hamiltons see "Affairs About Home" Boston Herald April 12, 1849; "A Card to Firemen" Boston Herald June 27, 1849 and "A Card to Fireman" Boston Herald June 30, 1849.

${ }^{13}$ Greenberg, Cause for Alarm, 60, 63, quotation on 59.

${ }^{14}$ Greenberg, Cause for Alarm, 76.

${ }_{15}$ "The Grand German Volksfest” Sunday Delta May 16, 1858.

${ }_{16}$ "The City" Times-Picayune May 17, 1858. 
${ }^{17}$ Scott Crawford argues that the type of football played at the Volksfest was an early version of soccer. The fact that the event was open to anyone and that large crowds were present suggests that the football was likely similar to other types of mob-style games and therefore was not, as Crawford contends, "a close parent of modern soccer." Scott Crawford, A History of Soccer in Louisiana 1858-2013 (n.p.: LAPrepsoccer publishing, 2013), quote on 25,30 .

${ }_{18}$ Peter Swain, "Cultural Continuity and Football in Nineteenth-century Lancashire" Sport in History vol. 28, 4 (2008), 568, 569. For a critique see R. W. Lewis, "Innovation not Invention: A Reply to Peter Swain Regarding the Professionalization of Association Football in England and its Diffusion" Sport in History vol. 30, 3 (2010): 475-488.

${ }_{19}^{19}$ Swain, "Cultural Continuity...", 568.

${ }_{20}$ "Boston Gymnasium - Julien Hall” Daily Atlas September 15, 1843; "The Games and Sports at East Boston" Boston Evening Transcript October 18, 1843; "Sheridan's Pistol Gallery" Boston Daily Bee March 24, 1845.

${ }_{21}$ "Amusement” Boston Courier September 16, 1843.

${ }_{22}$ "Athletic Games at East Boston” Boston Evening Transcript October 20, 1843.

${ }_{23}$ "Athletic Games" Daily Atlas October 21, 1843.

${ }_{24}$ "Athletic Games at East Boston” Boston Evening Transcript October 20, 1843.

${ }_{25}$ "Athletic Games at the Cricket and Archery Ground" Boston Evening Transcript November $1,1843$.

${ }_{26}$ “Three Days Fete!” Boston Evening Transcript July 18, 1844.

${ }^{27}$ U.S. Sanitary Commission, "Rules for Preserving the Health of the Soldiers" in Military Medical and Surgical Essays (Washington DC, 1865), 8-9.

${ }^{28}$ U.S. Sanitary Commission, A Report to the Secretary of War of the Operations of the Sanitary Commission, and Upon the Sanitary Conditions of the Volunteer Army, its Medical Staff, Hospitals, and Hospital Supplies (Washington DC: McGill and Withrow, 1861), 40 .

${ }_{29}$ "The Supplies and General Arrangements" New York Herald October 29, 1861.

${ }^{30}$ Bell Irvin Wiley, The Common Soldier in the Civil War. Book One: The Life of Billy Yank (New York: Grosset and Dunlap, 1952), 170; Bell Irvin Wiley, The Common 
Soldier in the Civil War. Book Two: The Life of Johnny Reb (New York: Grosset and Dunlap, 1952), 159. Some specific examples of individual units playing football include C. A. Stevens, Berden's United States Sharpshooters in the Army of the Potomac 18611865 (St. Paul, MN: 1892), 20; Alonso H. Quint, Record of the Second Massachusetts Infantry: 1861-1865 (Boston: James P. Walker, 1867), 52; “Camp Games" Charleston Mercury April 3, 1862. One interesting report suggests that indoor football was one of the only recreations for federal soldiers held at Libby prison in Richmond Virginia, "City Intelligence" Richmond Inquirer February 2, 1864.

${ }^{31}$ E. M. Haynes, A History of the Tenth Regiment VT. Vols. (Rutland, VT: The Tuttle Company, 1894), 25.

${ }^{32}$ Quote from "A Sad Affair has occurred at Camp Stevens..." Newport Mercury October 18, 1862. "Died of his Wounds" Providence Evening Press October 17, 1862. Eventually James O'Niel (later reports spell it as O'Neal and one gives his first name as John) was arrested for desertion and confessed that he had stabbed Simmons the previous autumn. O'Neal was eventually charged, convicted and sentenced to life in prison of the murder. "State of Rhode Island and Providence Plantations" Providence Evening Press October 24, 1862; "Examination of O'Niel "Providence Evening News September 5, 1863; "Supreme Court" Manufacturers' and Farmers' Journal October 22, 1863; “The John O’Neal” Newport Mercury January 16, 1864.

${ }^{33}$ John Rickards Betts, "Sporting Journalism in Nineteenth-Century America" American Quarterly vol. 5, 1 (spring, 1953), 40, 41, 42.

${ }_{34}$ "Memorial Number” New York Clipper February 1903.

${ }^{35}$ Thorn, Baseball in the Garden of Eden, 102, 104.

${ }_{36}$ "Have we any Foot-ball players among us?” New York Clipper December 13, 1856.

${ }_{37}$ "Winter Sports" New York Clipper December 20, 1856.

${ }_{38}$ "Winter Sports" New York Clipper December 20, 1856; Stonehenge [John Henry Walsh], Manual of British Rural Sports $2^{\text {nd }}$. edition (London: G. Routledge \& Co., 1856), 499-500.

${ }_{39}$ "Winter Sports” New York Clipper December 20, 1856.

${ }_{40}$ "Foot Ball” New York Clipper December 26, 1857.

${ }_{41}^{4}$ "Foot Ball” New York Clipper December 26, 1857. 
${ }^{42}$ John Augustin, "The Foot-ball Game" The Clipper November 20, 1858; "A Game of Football at Rugby" New York Clipper December 25, 1858.

${ }_{43}$ "The Game of Foot Ball" New York Clipper December 3, 1859.

" "Football in England" New York Clipper December 26, 1863.

4s "Rules of Football” New York Clipper December 3, 1864.

${ }_{46}$ "Football" Bell's Life in London November 28, 1863 and "The Football Association" Sporting Gazette November 28, 1863.

${ }^{47}$ David Kilpatrick, "NYC Originals: Thanksgiving Games of the St. George's Foot Ball Club" Society for American Soccer History http://www.ussoccerhistory.org/nycoriginals-thanksgiving-games-of-the-st-georges-foot-ball-club/. Accessed January 3, 2019.

${ }_{48}$ "The Cricket Match" New York Tribune August 19, 1843; "A Cricket Match..." TimesPicayune September 7, 1843; "The Great Game of Cricket" Public Ledger September 28, 1844.

${ }_{49}$ "One Interested in the Club," "St. George's Foot Ball Club" Spirit of the Times October 7, 1854, 402; "St. George's Foot Ball Club" The New York Clipper October 15, 1854.

so Kilpatrick, "NYC Originals”; “Sporting \&C.” New York Herald November 29, 1854.

${ }^{31}$ Waverly club listed no location and Cottage named no officers. "Attention Foot Ball" Sun September 14, 1859; "Attention" Sun February 29, 1860; "Notice - the Waverly Foot Ball Club” Sun September 8, 1860; “Attractive” Sun September 12, 1860.

${ }_{52}$ James H. Bready, Baseball in Baltimore (Baltimore: The Johns Hopkins University Press, 1998), 3, 6 .

${ }_{s 3}$ "United States Census, 1860", database with images, FamilySearch (https://familysearch.org/pal:/MM9.1.1/M698-Z9Z : 30 December 2015), accessed April 27, 2017.

${ }^{s 4}$ University of Maryland, Catalog 1858. Ancestry.com accessed May 1, 2017.

ss The basis for this claim is Winthrop S. Scudder, "An Historical Sketch of the Oneida Football Club of Boston 1862-1865" Massachusetts Historical Society, 1926.

s6 "City Intelligence" The Daily Exchange September 11, 1860; "Base Ball Match Between the Excelsior and Waverly Clubs" Daily Exchange October 18, 1860. 